\title{
Co and La supported on Zn-Hydrotalcite-derived material as efficient catalyst for ethanol steam reforming
}

\author{
C. Cerdá-Moreno, J.F. Da Costa-Serra, A. Chica* \\ Instituto de Tecnología Química (Universitat Politècnica de València-Consejo Superior de \\ Investigaciones Científicas), Avd. de los Naranjos s/n, 46022 Valencia (Spain). \\ *Corresponding author. Tel.: +34 9638770 00-78508; fax: +34 963877809 . \\ E-mail address: achica@itq.upv.es
}

\begin{abstract}
Four samples of Zn-hydrotalcite containing different amounts of Co $(5,10,20$, and $30 \mathrm{wt} . \%)$ have been synthesized and tested in the steam reforming of ethanol. The best results were obtained with the sample containing $20 \mathrm{wt} . \%$ of $\mathrm{Co}(20 \mathrm{CoHT})$, with a complete conversion of ethanol and yields to hydrogen close to the equilibrium (73 mol.\%). The physicochemical characterization of the samples by DRX, BET area and TPR indicates that the excellent performance exhibited by the sample containing $20 \mathrm{wt} . \%$ of Co is due to the higher percentage of reduced cobalt and lower crystallite size of metallic cobalt present in this sample $(11 \mathrm{~nm})$. Additional studies have been carried out to improve the stability of this catalytic material against deactivation by the incorporation of $1 \mathrm{wt} . \%$ of La. Stability studies were carried out using an industrial alcoholic waste as feed. Deactivation after 24 hours of reaction time was found lower for the catalyst containing La (20CoLaHT), confirming the positive effect of lanthanum on the catalytic stability. The results presented here show that it is possible to prepare a catalyst based on Co supported on Zn-hydrotalcite and promoted with La with improved ethanol conversion, high hydrogen selectivity, and high stability to produce hydrogen by the steam reforming of an industrial alcoholic waste without commercial value.
\end{abstract}

Keywords: Ethanol steam reforming, Hydrogen production, Hydrotalcite, LDHs, Cobalt catalyst, Alcoholic waste.

\section{Introduction.}

The search for an alternative energy source to our current energy system based on fossil fuels is one of the greatest challenges of our modern society. Among the different energy alternatives, hydrogen emerges with a great future [1-3]. Currently, hydrogen is not produced from renewable energy sources, representing an important drawback for its use as sustainable energetic alternative [4]. Thus, hydrogen should be produced from renewable energy sources such as biomass [5]. Particularly, the reforming of biomass derived compounds such as ethanol is considered an interesting option to produce hydrogen, because it can help to decrease the $\mathrm{CO}_{2}$ emissions, reducing the greenhouse effect [6-8]. The steam reforming of ethanol (SRE) is a very active area of research [9-12]. However, the reforming of industrial alcoholic wastes has not been properly studied and they can be an interesting raw material suitable for hydrogen production. The use of ethanol or alcoholic wastes to produce hydrogen entails a series of environmentally benefits compared with other fuels $[13,14]$. In literature, many reviews about catalytic materials applied to SRE have been published recently [15-18]. Co-based catalysts are widely accepted for SRE, exhibiting high catalytic activity [10, 18-24]. However, the development of an optimal catalyst for the steam reforming of industrial alcoholic wastes has not been properly reported yet. The importance of using alcoholic wastes obtained from the wine industry to produce hydrogen is due to the fact that a very high percentage (65\%) of world wine production is managed by European winegrowers [25]. The huge amounts of produced wine generate large amounts of solid and liquid wastes. The use of these liquid wastes in steam reforming reaction can be 
an excellent solution for their properly treatment and for the simultaneous production of renewable hydrogen.

In the development of optimal catalysts in the steam reforming of alcohols, the support selection and the methods used in their synthesis are considered key factors for their catalytic performances. From a bibliographic search is observed how the scientific interest in layered double hydroxides (LDHs) materials as support of catalysts is recently increasing [26-37]. Moreover, positive feedback can be observed in the use of LDHs in SRE [38-41]. In this work, we have studied the catalytic activity of hydrotalcite-like materials containing Co in which the $\mathrm{Mg}$ has been substituted by $\mathrm{Zn}$ ( $\mathrm{Zn}$-Al hydrotalcite-like materials), since $\mathrm{ZnO}$ has been used with good results as support in the SRE [42-47]. One of the advantages is related to the ability of $\mathrm{Zn}$ to decrease the formation of $\mathrm{CO}$, because $\mathrm{ZnO}$ favors water gas shift reaction (WGS) [48]. Another advantage is that the presence of $\mathrm{Zn}$ increases the reducibility of $\mathrm{Co}^{2+}$ [49]. In this study, the content of $\mathrm{Co}$ in $\mathrm{Zn}$-hydrotalcite was first optimized. Next, La was added to the best Co-Zn-hydrotalcite catalyst as stability promoter because the addition of La reduces the production of coke during the steam reforming reaction, obtaining a more stable catalyst [50-55]. Finally, the new formulation containing La was tested in the steam reforming of an industrial alcoholic waste from the wine industry. The physicochemical characterization of the Zn-hydrotalcite-derived catalysts with $\mathrm{Co}$ and $\mathrm{Co}$-La has been completed by XRD, BET surface area and TPR, finding interesting relationships with the catalytic results obtained in the steam reforming studies.

\section{Experimental.}

\subsection{Preparation of catalyst.}

$\mathrm{Zn}$-Al hydrotalcite-derived catalysts containing $\mathrm{Co}$ and $\mathrm{Co}-\mathrm{La}$ have been prepared by coprecipitation method. Two aqueous solutions, one acid and other basic, were initially prepared. The acid solution is formed by a mixture of $\mathrm{Zn}\left(\mathrm{NO}_{3}\right)_{2} \cdot 6 \mathrm{H}_{2} \mathrm{O}\left(\geq 97 \%\right.$, Sigma-Aldrich), $\mathrm{Al}\left(\mathrm{NO}_{3}\right)_{3} \cdot 9 \mathrm{H}_{2} \mathrm{O}(\geq 98 \%$, Sigma-Aldrich) and $\mathrm{Co}\left(\mathrm{NO}_{3}\right)_{2} \cdot 6 \mathrm{H}_{2} \mathrm{O}(\geq 98 \%$, Sigma-Aldrich) in the adequate proportion to obtain 5, 10, 20, and $30 \mathrm{wt} . \%$ of Co. The general formula of catalysts is $\left[\mathrm{M}(\mathrm{II})(1-\mathrm{x}) \mathrm{M}(\mathrm{III})_{\mathrm{x}}(\mathrm{OH})_{2}\right]^{\mathrm{x}+}\left(\mathrm{A}^{\mathrm{n}-\mathrm{x} / \mathrm{n})} \cdot \mathrm{mH}_{2} \mathrm{O}\right.$; where $\mathrm{M}(\mathrm{II})$ are $\mathrm{Zn} / \mathrm{Co}$ and $\mathrm{M}(\mathrm{III})$ are $\mathrm{Al} / \mathrm{La}$ according to each case, and $\mathrm{A}^{\mathrm{n}-}$ is $\mathrm{NO}_{3}{ }^{-}$. The ratio between trivalent metals and the sum of trivalent and divalent metals was 0.2 . The basic solution is formed by a mixture of $\mathrm{NaNO}_{3}(\geq 98 \%$, Scharlab) and $\mathrm{NaOH}(\geq 98 \%$, Scharlab). Both solutions were mixed using a syringe pump under constant stirring until obtaining a gel, which is deposited in a polypropylene bottle and kept in an oven at $333 \mathrm{~K}$ for 18 hours. After, the gel is filtered, washed and dried in an oven at $373 \mathrm{~K}$ overnight. Finally, it is calcined at $873 \mathrm{~K}$ in an oven for 3 hours obtaining the catalysts named as $5 \mathrm{CoHT}, 10 \mathrm{CoHT}, 20 \mathrm{CoHT}$ and 30CoHT. Following the same method is obtained the sample containing $1 \mathrm{wt} . \%$ of La (20CoLaHT) using $\mathrm{La}\left(\mathrm{NO}_{3}\right)_{3} \cdot 6 \mathrm{H}_{2} \mathrm{O}\left(\geq 98 \%\right.$, Sigma-Aldrich) as lanthanum precursor. The amount of $\mathrm{Na}^{+}$in the catalysts is under 0.05 wt.\%.

\subsection{Characterization techniques.}

The catalysts used in this study have been subjected to X-ray fluorescence (XRF) in a MiniPal4 apparatus (PANalytical) to determine the amount of Co and La. Moreover, the amount of $\mathrm{Na}^{+}$was determined by atomic absorption spectrophotometry (AAS) in a Varian Spectra A-10 Plus apparatus. Textural properties were measured using an ASAP 2420 apparatus (Micromeritics) at $77 \mathrm{~K}$. The X-ray diffraction has been carried out at room temperature in a Panalytical CubiX diffractometer using $\mathrm{CuK} \alpha$ radiation. The identification of the crystalline phases has been carried out using the X'Pert HighScore Plus software. The reduction behaviors were studied by temperature programmed reduction (TPR) in Micromeritics Autochem 2910 equipment. The TPR experiments were carried out with the online analysis of the products evolved.

\subsection{Catalytic study.}

The reaction experiments were carried out in a continuous fixed bed reactor at atmospheric pressure, $\mathrm{H}_{2} \mathrm{O} / \mathrm{EtOH}$ molar ratio of 10 , GHSV of $4700 \mathrm{~h}^{-1}\left(\mathrm{EtOH}+\mathrm{H}_{2} \mathrm{O}\right)$ and different reaction temperatures (673-873 $\mathrm{K})$. The reactor was loaded with $0.3 \mathrm{~mL}$ of catalyst $(\sim 0.25 \mathrm{~g})$, diluted with $3 \mathrm{~g}$ of carborundum ( $\mathrm{SiC})$. Before reaction the samples were reduced with $\mathrm{H}_{2}$ flow $\left(100 \mathrm{~mL} \cdot \mathrm{min}^{-1}\right)$ at $873 \mathrm{~K}$ for $2 \mathrm{~h}$. The reaction compounds have been analyzed in a Varian 3800-GC equipped with two columns (TRB-5, L=30 m, DI=0.25 mm; CarboSieve SII, L=3 m, DI=2.1 mm) and two detectors, a thermal conductivity (TCD) and flame ionization (FID) using their corresponding standards. 
An alcoholic waste supplied by Destilerías San Valero has been used in the last part of this paper to carry out the stability studies. The composition of this industrial alcoholic waste is shown in Table 1 . The identification and quantification of impurities present in the alcoholic waste was carried out with a chromatograph (Shimadzu GC-17A) equipped with a PACKED injector, FID detector and steel packed column (VINICOL, $\mathrm{L}=2 \mathrm{~m}, \mathrm{ID}=2 \mathrm{~mm}$ ) using their corresponding standards. Stability tests with this alcoholic waste were carried out at atmospheric pressure, $\mathrm{H}_{2} \mathrm{O} / \mathrm{EtOH}$ contained in the alcoholic waste of 10 (molar ratio), GHSV of $4700 \mathrm{~h}^{-1}\left(\mathrm{EtOH}+\mathrm{H}_{2} \mathrm{O}\right)$ and $873 \mathrm{~K}$.

Table 1. Composition of the industrial alcoholic waste used in the stability studies.

\begin{tabular}{ll}
\hline Compound & Concentration \\
\hline Water & $80.12 \mathrm{wt} . \%$ \\
Ethanol & $19.64 \mathrm{wt} . \%$ \\
Impurities & $0.24 \mathrm{wt} . \%$ \\
Acetaldehyde & $2.17 \mathrm{mg} / \mathrm{L}$ \\
Methanol & $115.88 \mathrm{mg} / \mathrm{L}$ \\
2-Propanol & $17.15 \mathrm{mg} / \mathrm{L}$ \\
n-Propanol & $847.47 \mathrm{mg} / \mathrm{L}$ \\
2-Butanol & $870.72 \mathrm{mg} / \mathrm{L}$ \\
Isobutanol & $41.89 \mathrm{mg} / \mathrm{L}$ \\
2-Methyl-1-Butanol & $1.7 \mathrm{mg} / \mathrm{L}$ \\
$\mathrm{SO}_{2}$ & $10 \mathrm{mg} / \mathrm{L}$ \\
\hline
\end{tabular}

\section{Results and discussion.}

\subsection{Characterization.}

X-ray diffraction patterns of synthesized hydrotalcite-derived materials with different Co content are shown in Figure 1. All the diffraction peaks can be attributed to a typical hydrotalcite structure [56, 57], confirming that the catalytic materials have been correctly prepared.

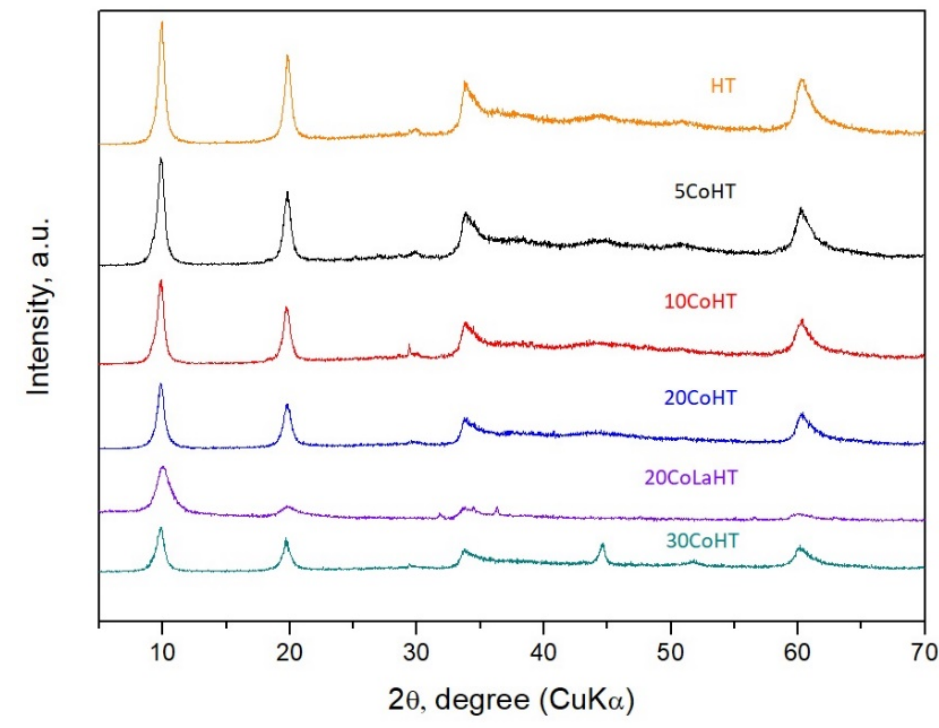

Figure 1. XRD of hydrotalcite-like materials containing Co and La.

Once the correct synthesis of the catalysts was verified, the catalytic materials were calcined at $873 \mathrm{~K}$ to remove the precursor compounds used for the incorporation of $\mathrm{Co}$ and La. After calcination the catalysts were reduced in flow of $\mathrm{H}_{2}$ at $873 \mathrm{~K}$ before reaction. Figure 2 shows the XRD of calcined and reduced catalysts. All the calcined materials (Figure 2, left) present similar XRD pattern with diffraction peaks corresponding to $\mathrm{ZnO}$ [Ref. code 01-089-0510], $\mathrm{ZnAl}_{2} \mathrm{O}_{4}$ [Ref. code 00-005-0669], and $\mathrm{Co}_{3} \mathrm{O}_{4}$ phases [Ref. code 00-042-1467] [58, 59]. For the catalyst containing La, reflections due to $\mathrm{La}_{2} \mathrm{O}_{3}$ phase or other 
lanthanum phases were not observed in the calcined sample. This observation can be explained by the small amount of La in the sample (1 wt.\%) and because it may be in an amorphous state [60].
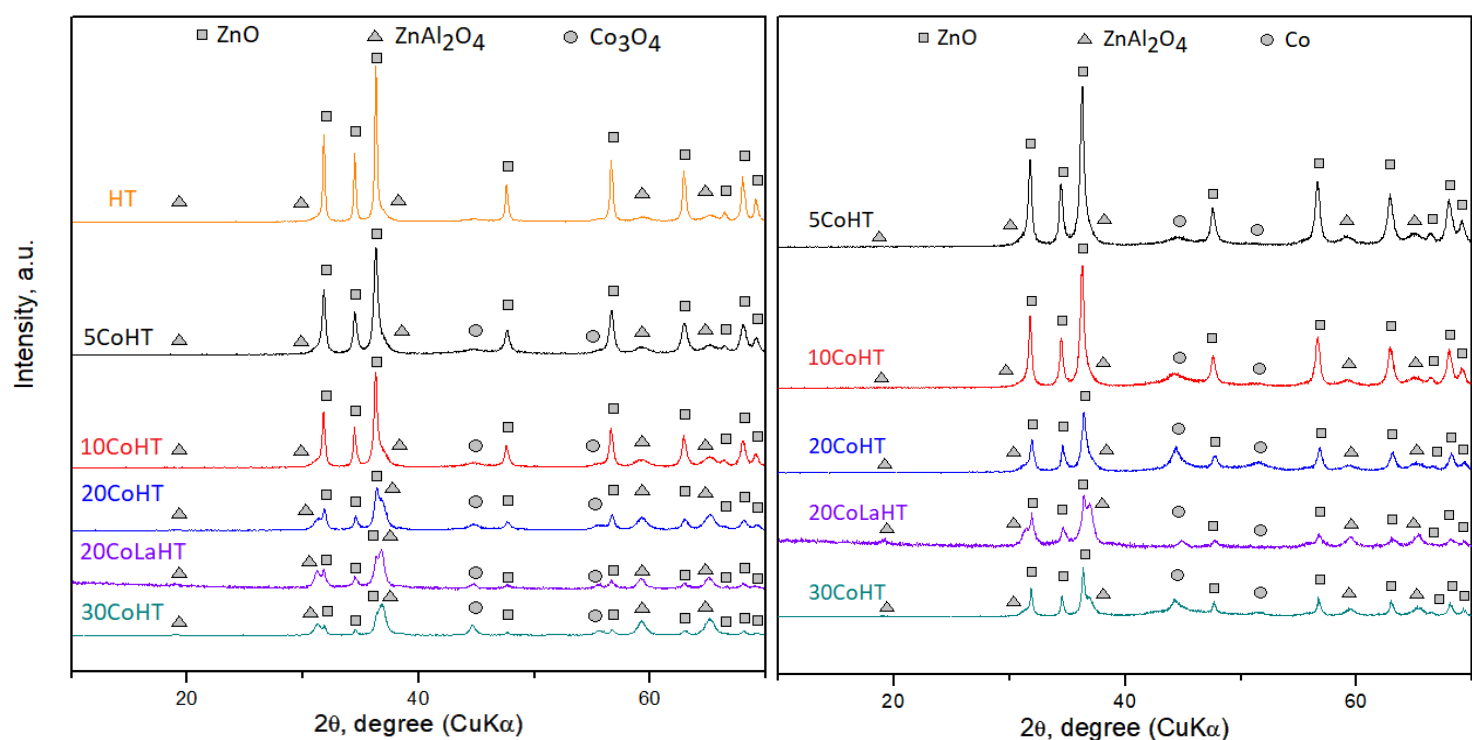

Figure 2. (Left) XRD of Zn-hydrotalcite-derived materials containing Co and La calcined at 873K. (Right) XRD of Znhydrotalcite-derived materials containing $\mathrm{Co}$ and La calcined and after reduction at $873 \mathrm{~K}$.

For the reduced catalysts, the main peaks corresponding to the $\mathrm{Co}_{3} \mathrm{O}_{4}$ disappeared, appearing the diffraction peaks corresponding to $\mathrm{Co}^{0}$ phase [Ref. code 00-015-0806] (Figure 2, right). On the other hand, the diffraction peaks corresponding to the support $\left(\mathrm{ZnO}\right.$ and $\left.\mathrm{ZnAl}_{2} \mathrm{O}_{4}\right)$ were also present in the reduced material. The crystallite size of metallic cobalt $\left(\mathrm{Co}^{0}\right)$ has been also determined from the XRD of the reduced catalysts using the Scherrer equation [61]. As it can be seen in Table 2, the average crystallite size of $\mathrm{Co}^{0}$ increases with the load of Co. Specifically, the sample $5 \mathrm{CoHT}$ with $5 \mathrm{wt}$. \% of Co presented the lowest size ( $7 \mathrm{~nm}$ ), while the sample 30CoHT with $30 \mathrm{wt} . \%$ of Co presented the highest size $(14 \mathrm{~nm})$. This is an expected result if it is considered that increasing the load of $\mathrm{Co}$, the sintering of the metallic phase is favored by the proximity between metallic crystallites.

Table 2 also shows the specific surface area and cobalt/lanthanum content for the different catalysts studied in this paper. As it can be seen, specific surface area decreases when Co or Co and La are incorporated. Initial specific surface area of $58 \mathrm{~m}^{2} / \mathrm{g}$ for the sample HT decreases to $25-40 \mathrm{~m}^{2} / \mathrm{g}$ when Co or Co and La are added. This decrease in area could be explained taking into account that cobalt in calcined samples is present as $\mathrm{Co}_{3} \mathrm{O}_{4}$ that has a very low surface area $\left(<1 \mathrm{~m}^{2} / \mathrm{g}\right)$. The presence of $\mathrm{Co}_{3} \mathrm{O}_{4}$ will have a very low contribution to the total surface area of the final catalytic material. Thus, the cobalt incorporation would lead to a "dilution effect", which could explain the reduction of the surface area detected [20].

Table 2. Co and La content, BET surface area, crystallite size of $\mathrm{Co}^{0}$ determined by $\mathrm{XRD}$ and reduction degree for the catalysts studied in this work.

\begin{tabular}{lcccc}
\hline Sample & $\begin{array}{c}\text { BET surface area } \\
\left(\mathbf{m}^{\mathbf{2}} / \mathbf{g}\right)\end{array}$ & $\begin{array}{c}\text { Co/La composition } \\
\text { determined by } \\
\text { XRF, wt. } \%\end{array}$ & $\begin{array}{c}\mathbf{C o}^{\mathbf{0}} \text { crystallite } \\
\text { size determined } \\
\text { by XRD (nm) }\end{array}$ & $\begin{array}{c}\text { Reduction degree } \\
\text { at 873 K, \% }\end{array}$ \\
\hline HT & 58 & $-/-$ & - & - \\
5CoHT & 35 & $5.1 /-$ & 7 & 96 \\
10CoHT & 36 & $10.0 /-$ & 10 & 92 \\
20CoHT & 35 & $20.5 /-$ & 11 & 86 \\
30CoHT & 38 & $29.2 /-$ & 14 & 71 \\
20CoLaHT & 25 & $20.1 / 0.9$ & 12 & 69 \\
\hline
\end{tabular}

The reduction properties of the calcined catalysts have been studied by temperature-programmed reduction (TPR). The reduction curves are shown in Figure 3. It is observed that all the catalysts present two main 
reduction peaks. The first peak appears around $700 \mathrm{~K}$ and the second appears in a wider range of temperatures, between 850 and $950 \mathrm{~K}$. These two peaks correspond to the reduction in two stages of $\mathrm{Co}_{3} \mathrm{O}_{4}$ oxide, which would be reduced first to $\mathrm{CoO}$ and then to $\mathrm{Co}^{0}$ [49]. These results agree with the species observed in the XRD section of the catalysts calcined at $873 \mathrm{~K}$ and reduced with hydrogen at $873 \mathrm{~K}$. Small changes can be found in the reduction temperature values for the second reduction peaks, suggesting that slight differences in the interaction between cobalt and support would be occurring in the different catalysts.

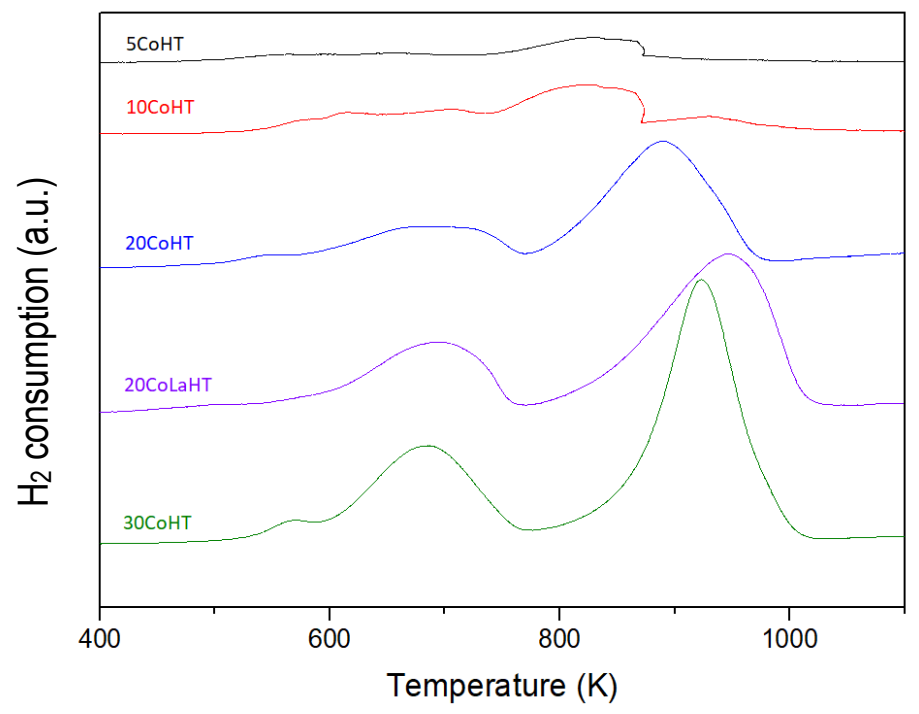

Figure 3. TPR profiles of the catalytic materials studied in this paper.

The reduction degree of the different catalysts has been also determined at $873 \mathrm{~K}$. This temperature was used to reduce the calcined catalysts before starting the steam reforming studies. As it can be seen in Table 2 , high reduction degrees are achieved for the samples containing low charge of Co. On the other hand, the presence of La does not seem to favor the reduction of Co at $873 \mathrm{~K}$.

\subsection{Catalytic activity.}

In Figure 4 the values of ethanol conversion and hydrogen selectivity for the catalysts with different cobalt loadings are shown. The values given in this study were obtained after 5 hours of reaction, when stationary steady state was reached. In the experiments where temperature was varied, the activity at the first temperature tested $(673 \mathrm{~K})$ was measured again at the end of each experiment. In this way, it can be assured that the values for all the temperatures are reliable.

Initially, it was studied the effect of the cobalt content in the steam reforming of ethanol. Figure 4 shows the variation of the ethanol conversion with the amount of cobalt at $673 \mathrm{~K}$. As it can be seen, the complete conversion of ethanol is obtained for loads of Co of $20 \mathrm{wt} . \%$ or higher. A combination of the low crystallite size of $\mathrm{Co}^{0}(11 \mathrm{~nm})$ and high reduction degree $(86 \%)$ could explain the better catalytic results presented by the sample 20CoHT. Regarding the selectivity of hydrogen, it can be observed that the highest values are also obtained for the sample containing $20 \mathrm{wt} . \%$ of $\mathrm{Co}$, remaining nearly constant for higher loadings. In summary, these results indicate that it could be prepared a Zn-hydrotalcite-derived catalysts containing 20 wt.\% of Co with high ethanol conversion and hydrogen selectivity in the steam reforming of ethanol. 


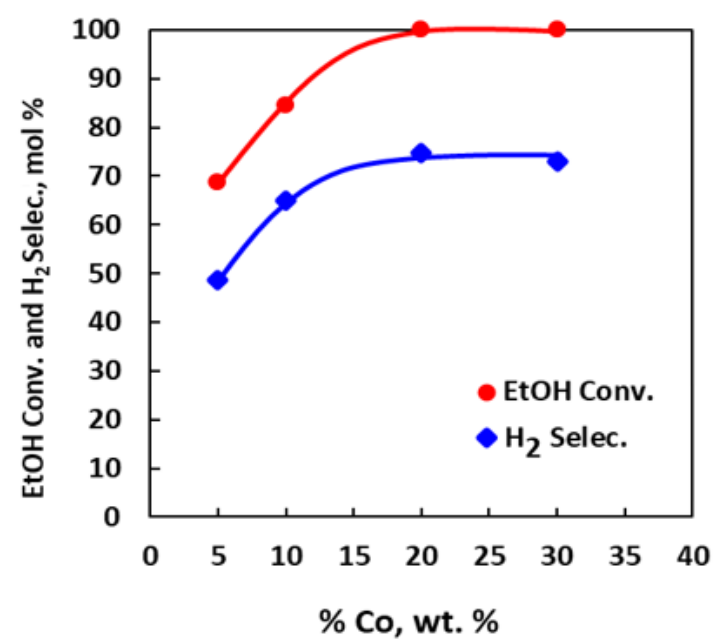

Figure 4. Conversion of ethanol and $\mathrm{H}_{2}$ selectivity versus Co content. Reaction conditions: $673 \mathrm{~K}, \mathrm{H}_{2} \mathrm{O} / \mathrm{EtOH}=10$, GHSV=4700 h-1 and atmospheric pressure.

Products distribution have been also studied at $673 \mathrm{~K}$ and they are shown in Table 3 . As it can be seen the catalyst containing $20 \mathrm{wt} . \%$ of Co produces the lowest amounts of $\mathrm{CH}_{4}, \mathrm{CO}$ and other undesired byproducts $\left(\mathrm{C}_{2} \mathrm{H}_{4}, \mathrm{CH}_{3} \mathrm{COOH}, \mathrm{C}_{2} \mathrm{H}_{4} \mathrm{O}\right.$ and $\left.\mathrm{C}_{3} \mathrm{H}_{6} \mathrm{O}\right)$. It must be considered that the production of several of these byproducts can affect the stability of the catalyst since some of them $\left(\mathrm{C}_{2} \mathrm{H}_{4}\right)$ are coke precursor.

Table 3. Products distribution for the ethanol steam reforming (selectivity values, $\mathrm{mol} \%$ ). Reaction conditions: $673 \mathrm{~K}, \mathrm{H}_{2} \mathrm{O} / \mathrm{EtOH}=$ $10, \mathrm{GHSV}=4700 \mathrm{~h}^{-1}$ and atmospheric pressure.

\begin{tabular}{lccccccc}
\hline Catalyst & $\mathbf{C H}_{4}$ & $\mathbf{C O}$ & $\mathbf{C O}_{2}$ & $\mathbf{C}_{2} \mathbf{H}_{4}$ & $\mathbf{C H}_{3} \mathbf{C O O H}$ & $\mathbf{C}_{2} \mathbf{H}_{4} \mathbf{O}$ & $\mathbf{C}_{3} \mathbf{H}_{6} \mathbf{O}$ \\
\hline 5CoHT & 6.9 & 5.4 & 3.5 & 0.4 & 0.2 & 34.0 & 0.9 \\
10CoHT & 6.6 & 2.3 & 17.1 & 0.3 & 0.3 & 3.3 & 0.2 \\
20CoHT & 5.0 & 1.2 & 19.5 & 0.2 & 0.2 & 0.2 & 0.1 \\
30CoHT & 5.3 & 1.4 & 21.7 & 0.4 & 0.4 & 0.5 & 0.2 \\
\hline
\end{tabular}

Considering the excellent results obtained by the $20 \mathrm{CoHT}$ catalyst, it was decided to improve its catalytic stability incorporating La, a known stability promoter, which acts decreasing the coke deposition [50-55]. The catalyst $20 \mathrm{CoLaHT}$ containing $1 \mathrm{wt} . \%$ of La was prepared and tested in steam reforming of ethanol at different reaction temperatures. The results are shown in Table 4. In general, the two catalysts studied in this section present a high ethanol conversion values, with small differences between them. As it can be seen, a higher conversion of ethanol is exhibited by the sample containing La (20CoLaHT), with a complete conversion of ethanol in all the reaction temperatures here studied. Moreover, a higher hydrogen selectivity is also achieved, and a lower concentration of not desired byproducts is obtained, particularly at high reaction temperatures. These results suggest that the addition of La would have positive effects on the catalytic performance, improving the conversion of ethanol and decreasing the formation of undesired byproducts, such as $\mathrm{C}_{2} \mathrm{H}_{4}$, which is related to coke formation. 
Table 4. Ethanol conversion and products distribution (selectivity values, mol\%) obtained at different temperatures with the catalyst $20 \mathrm{CoHT}$ and 20CoLaHT. Reaction conditions: $\mathrm{H}_{2} \mathrm{O} / \mathrm{EtOH}=10, \mathrm{GHSV}=4700 \mathrm{~h}^{-1}$ and atmospheric pressure.

\begin{tabular}{lcccccccccc}
\hline Catalyst & $\mathbf{T}^{\mathrm{a}}, \mathbf{K}$ & $\begin{array}{c}\% \\
\text { Conv. }\end{array}$ & $\mathrm{CH}_{4}$ & $\mathbf{C O}$ & $\mathrm{CO}_{2}$ & $\mathrm{H}_{2}$ & $\mathrm{C}_{2} \mathrm{H}_{4}$ & $\mathrm{CH}_{3} \mathrm{COOH}$ & $\mathrm{C}_{2} \mathrm{H}_{4} \mathrm{O}$ & $\mathrm{C}_{3} \mathrm{H}_{6} \mathrm{O}$ \\
\hline \multirow{2}{*}{ 20CoHT } & 673 & 99.0 & 5.0 & 1.2 & 19.5 & 73.6 & 0.2 & 0.2 & 0.2 & 0.1 \\
& 773 & 100.0 & 3.3 & 4.0 & 18.7 & 73.7 & 0.2 & 0.1 & 0.0 & 0.0 \\
& 873 & 100.0 & 4.0 & 4.6 & 18.4 & 72.8 & 0.1 & 0.1 & 0.0 & 0.0 \\
\hline \multirow{2}{*}{ 20CoLaHT } & 773 & 100.0 & 0.9 & 2.2 & 21.7 & 75.2 & 0.0 & 0.0 & 0.0 & 0.0 \\
& 673 & 100.0 & 5.9 & 1.0 & 18.5 & 74.6 & 0.0 & 0.0 & 0.0 & 0.0 \\
& 873 & 100.0 & 1.1 & 3.0 & 20.8 & 75.1 & 0.0 & 0.0 & 0.0 & 0.0 \\
\hline
\end{tabular}

$20 \mathrm{CoHT}$ and 20CoLaHT have been also tested using an industrial alcoholic waste supplied by Destilerías San Valero. The composition of this waste was presented in Table 1. The catalytic results are presented in Table 5 and Figure 5. As it can be seen, both catalysts present similar catalytic activity with a complete conversion of ethanol and a high hydrogen selectivity over the entire range of temperatures here studied. The presence of impurities mentioned in Table 1 was not detected in the exhaust gas for any of the catalysts. Thus, they were completely reformed with both catalysts. It should be noted that 20CoLaHT presents slightly better catalytic results at high temperatures, similar to the catalytic behavior above described in the steam reforming of ethanol. Additionally, it was not detected the production of undesired byproducts such as $\mathrm{C}_{2} \mathrm{H}_{4}, \mathrm{CH}_{3} \mathrm{COOH}, \mathrm{C}_{2} \mathrm{H}_{4} \mathrm{O}$ and $\mathrm{C}_{3} \mathrm{H}_{6} \mathrm{O}$ for the sample containing La. Besides, deactivation of the sample containing La was not detected during the 24 hours of experiments, while the catalyst without La started to deactivate after 10 hours of reaction time (Figure 5), where a progressive drop in the ethanol conversion is observed.

Table 5. Catalytic results for the steam reforming of the alcoholic waste (conversion and selectivity values, mol \%). Reaction conditions: $\mathrm{H}_{2} \mathrm{O} / \mathrm{EtOH}=10, \mathrm{GHSV}=4700 \mathrm{~h}^{-1}$ and atmospheric pressure.

\begin{tabular}{lcccccccccc}
\hline Catalyst & $\mathbf{T}^{\mathbf{a}}, \mathbf{K}$ & $\begin{array}{c}\text { \% Conv. } \\
\text { EtOH }\end{array}$ & $\mathbf{C H}_{4}$ & $\mathbf{C O}$ & $\mathbf{C O}_{2}$ & $\mathbf{H}_{2}$ & $\mathbf{C}_{2} \mathbf{H}_{4}$ & $\mathbf{C H}_{3} \mathbf{C O O H}$ & $\mathbf{C}_{2} \mathrm{H}_{4} \mathbf{O}$ & $\mathbf{C}_{3} \mathrm{H}_{6} \mathbf{O}$ \\
\hline \multirow{2}{*}{ 20CoHT } & 673 & 98.7 & 3.5 & 1.1 & 22.3 & 72.3 & 0.3 & 0.2 & 0.1 & 0.2 \\
& 773 & 100.0 & 1.0 & 2.7 & 21.1 & 74.7 & 0.2 & 0.2 & 0.0 & 0.1 \\
& 873 & 100.0 & 3.1 & 2.9 & 20.2 & 73.5 & 0.1 & 0.1 & 0.0 & 0.1 \\
\hline \multirow{2}{*}{ 20CoLaHT } & 673 & 99.2 & 2.8 & 1.2 & 21.4 & 74.6 & 0.0 & 0.0 & 0.0 & 0.0 \\
& 773 & 100.0 & 0.9 & 2.8 & 21.2 & 75.1 & 0.0 & 0.0 & 0.0 & 0.0 \\
& 873 & 100.0 & 1.7 & 4.3 & 19.1 & 74.9 & 0.0 & 0.0 & 0.0 & 0.0 \\
\hline
\end{tabular}

The acetaldehyde selectivity for $20 \mathrm{CoHT}$ also increased after 10 hours of reaction (from $0.0 \mathrm{~mol} \%$ to 5.2 mol\%), supporting also that deactivation of the catalyst is occurring $[20,46]$. Thus, the lanthanum addition seems to have a positive effect on catalyst performance improving the catalytic activity and avoiding the deactivation of the catalyst in the presence of the impurities contained in the alcoholic waste here used. Fatsikostas et al $[62,63]$ reported that the La incorporation improves the catalytic stability during the steam reforming of ethanol by the formation of $\mathrm{La}_{2} \mathrm{O}_{2} \mathrm{CO}_{3}$ species, which react with surface carbon deposits. We have not detected the presence of these species by XRD or their decomposition products during the TPR studies. It is possible that the low concentration of La presents in our sample $(<1 \mathrm{wt} . \%)$ could justify this fact. 

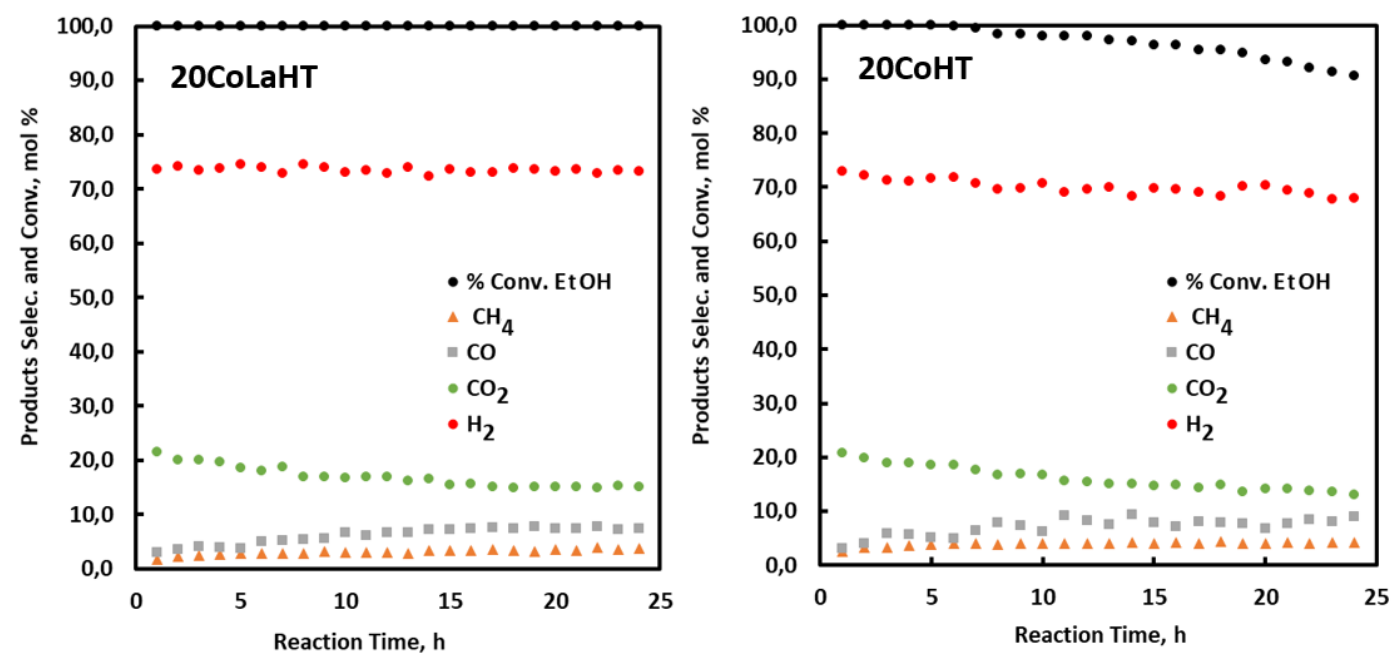

Figure 5. Products selectivity and conversion of ethanol versus reaction time for $20 \mathrm{CoLaHT}$ and $20 \mathrm{CoHT}$ catalysts using alcoholic waste as feed. Reaction conditions: $\mathrm{H}_{2} \mathrm{O} / \mathrm{EtOH}=10, \mathrm{GHSV}=4700 \mathrm{~h}^{-1}$, atmospheric pressure and at $873 \mathrm{~K}$.

Additional studies are being carried out to acquire more knowledge about the high catalytic performance and stability exhibited by the sample containing lanthanum. Specifically, it is being studied the influence of the La loading, superficial composition of the catalyst by XPS and the characterization of the fresh and of the used catalysts by IR and Raman spectroscopy.

All the results presented here show that it is possible to synthesize ethanol steam reforming catalysts based on Co supported on hydrotalcite-type material with high catalytic activity and hydrogen selectivity, which are able to reduce the formation of undesired byproducts $\left(\mathrm{CO}, \mathrm{CH}_{4}, \mathrm{C}_{2} \mathrm{H}_{4}, \mathrm{CH}_{3} \mathrm{COOH}, \mathrm{C}_{2} \mathrm{H}_{4} \mathrm{O}\right.$ and $\left.\mathrm{C}_{3} \mathrm{H}_{6} \mathrm{O}\right)$ when industrial alcoholic waste is used as feed.

\section{Conclusions.}

Zn-hydrotalcite-derived material with different amounts of Co have been synthesized and tested in the steam reforming of ethanol. The catalytic results show that the sample containing $20 \mathrm{wt} \%$ of Co presents the highest ethanol conversion values and hydrogen selectivity together with the lowest concentration of $\mathrm{CO}, \mathrm{CH}_{4}$ and other undesired byproducts $\left(\mathrm{C}_{2} \mathrm{H}_{4}, \mathrm{C}_{2} \mathrm{H}_{4} \mathrm{O}, \mathrm{CH}_{3} \mathrm{COOH}\right.$, and $\left.\mathrm{C}_{3} \mathrm{H}_{6} \mathrm{O}\right)$. This result could be explained by combining the small crystallite size of metallic cobalt present in this material together with its high reduction degree. It has been also seen that the addition of La increases the catalytic stability of this cobalt catalyst, keeping its ethanol conversion unaltered after 24 hours of reaction, when an industrial alcoholic waste containing several impurities is used as feed.

\section{Acknowledgements}

Cristina Cerdá-Moreno acknowledges the financial support from the Spanish Government through predoctoral training fellowships for "Centros de Excelencia Severo Ochoa" (SEV-2016-0683). The doctor Javier Francisco Da Costa Serra wants to have some words of thanks toward CSIC for granted the scholarship predoctoral-JAE-CSIC. We also thanks to Destilerías San Valero for supplying us the samples of the alcoholic wastes used in this work.

\section{References}

[1] Liguras DK, Kondarides DI, Verykios XE. Production of hydrogen for fuel cells by steam reforming of ethanol over supported noble metal catalysts. Applied Catalysis B: Environmental. 2003;43:345-54. 
[2] Sohn H, Ozkan US. Cobalt-Based Catalysts for Ethanol Steam Reforming: An Overview. Energy \& Fuels. 2016;30:5309-22.

[3] da Silva Veras T, Mozer TS, da Costa Rubim Messeder dos Santos D, da Silva César A. Hydrogen: Trends, production and characterization of the main process worldwide. International Journal of Hydrogen Energy. 2017;42:2018-33.

[4] Muradov N. Low to near-zero $\mathrm{CO}_{2}$ production of hydrogen from fossil fuels: Status and perspectives. International Journal of Hydrogen Energy. 2017;42:14058-88.

[5] Ma F, Hanna MA. Biodiesel production: a review1. Bioresource Technology. 1999;70:1-15.

[6] Maggio G, Freni S, Cavallaro S. Light alcohols/methane fuelled molten carbonate fuel cells: a comparative study. Journal of Power Sources. 1998;74:17-23.

[7] F. Brown L. A comparative study of fuels for on-board hydrogen production for fuel-cell-powered automobiles. International Journal of Hydrogen Energy. 2001;26:381-97.

[8] Ni M, Leung DYC, Leung MKH, Sumathy K. An overview of hydrogen production from biomass. Fuel Processing Technology. 2006;87:461-72.

[9] Haryanto A, Fernando S, Murali N, Adhikari S. Current Status of Hydrogen Production Techniques by Steam Reforming of Ethanol: A Review. Energy \& Fuels. 2005;19:2098-106.

[10] Vaidya PD, Rodrigues AE. Insight into steam reforming of ethanol to produce hydrogen for fuel cells. Chemical Engineering Journal. 2006;117:39-49.

[11] Huber GW, Iborra S, Corma A. Synthesis of Transportation Fuels from Biomass: Chemistry, Catalysts, and Engineering. Chemical Reviews. 2006;106:4044-98.

[12] Ni M, Leung DYC, Leung MKH. A review on reforming bio-ethanol for hydrogen production. International Journal of Hydrogen Energy. 2007;32:3238-47.

[13] Comas J, Mariño F, Laborde M, Amadeo N. Bio-ethanol steam reforming on Ni/Al2O3 catalyst. Chemical Engineering Journal. 2004;98:61-8.

[14] Fierro V, Akdim O, Provendier H, Mirodatos C. Ethanol oxidative steam reforming over Ni-based catalysts. Journal of Power Sources. 2005;145:659-66.

[15] Mattos LV, Jacobs G, Davis BH, Noronha FB. Production of Hydrogen from Ethanol: Review of Reaction Mechanism and Catalyst Deactivation. Chemical Reviews. 2012;112:4094-123.

[16] Sun J, Wang Y. Recent Advances in Catalytic Conversion of Ethanol to Chemicals. ACS Catalysis. 2014;4:1078-90.

[17] LeValley TL, Richard AR, Fan M. The progress in water gas shift and steam reforming hydrogen production technologies - A review. International Journal of Hydrogen Energy. 2014;39:16983-7000.

[18] Contreras JL, Salmones J, Colín-Luna JA, Nuño L, Quintana B, Córdova I, et al. Catalysts for H2 production using the ethanol steam reforming (a review). International Journal of Hydrogen Energy. 2014;39:18835-53.

[19] de la Peña O’Shea VA, Nafria R, Ramírez de la Piscina P, Homs N. Development of robust Co-based catalysts for the selective H2-production by ethanol steam-reforming. The Fe-promoter effect. International Journal of Hydrogen Energy. 2008;33:3601-6.

[20] Da Costa-Serra JF, Chica A. Bioethanol steam reforming on Co/ITQ-18 catalyst: Effect of the crystalline structure of the delaminated zeolite ITQ-18. International Journal of Hydrogen Energy. 2011;36:3862-9.

[21] Palma V, Castaldo F, Ciambelli P, Iaquaniello G, Capitani G. On the activity of bimetallic catalysts for ethanol steam reforming. International Journal of Hydrogen Energy. 2013;38:6633-45.

[22] Yu S-W, Huang H-H, Tang C-W, Wang C-B. The effect of accessible oxygen over Co3O4-CeO2 catalysts on the steam reforming of ethanol. International Journal of Hydrogen Energy. 2014;39:20700-11. [23] Zhao X, Lu G. Modulating and controlling active species dispersion over Ni-Co bimetallic catalysts for enhancement of hydrogen production of ethanol steam reforming. International Journal of Hydrogen Energy. 2016;41:3349-62.

[24] Ando Y, Matsuoka K. Role of Fe in Co-Fe particle catalysts for suppressing CH4 production during ethanol steam reforming for hydrogen production. International Journal of Hydrogen Energy. 2016;41:12862-8.

[25] European Wine: a solid pillar of the European Union economy. In: Vins- CCEdE, editor. http://www.ceev.eu/about-the-eu-wine-sector2016.

[26] Li D, Cai Y, Ding Y, Li R, Lu M, Jiang L. Layered double hydroxides as precursors of Cu catalysts for hydrogen production by water-gas shift reaction. International Journal of Hydrogen Energy. 2015;40:10016-25.

[27] Zhang L, Hui KN, Hui KS, Chen X, Chen R, Lee H. Role of graphene on hierarchical flower-like NiAl layered double hydroxide-nickel foam-graphene as binder-free electrode for high-rate hybrid supercapacitor. International Journal of Hydrogen Energy. 2016;41:9443-53. 
[28] Li M, Yuan P, Guo S, Liu F, Cheng JP. Design and synthesis of Ni-Co and Ni-Mn layered double hydroxides hollow microspheres for supercapacitor. International Journal of Hydrogen Energy. 2017;42:28797-806.

[29] Eshghi A, kheirmand M. Graphene/Ni-Fe layered double hydroxide nano composites as advanced electrode materials for glucose electro oxidation. International Journal of Hydrogen Energy. 2017;42:15064-72.

[30] Mostajeran M, Prévot V, Mal SS, Mattiussi E, Davis BR, Baker RT. Base-metal catalysts based on porous layered double hydroxides for alkaline-free sodium borohydride hydrolysis. International Journal of Hydrogen Energy. 2017;42:20092-102.

[31] Kim W, Mohaideen KK, Seo DJ, Yoon WL. Methanol-steam reforming reaction over Cu-Al-based catalysts derived from layered double hydroxides. International Journal of Hydrogen Energy. 2017;42:2081-7.

[32] Di Vona ML, Casciola M, Donnadio A, Nocchetti M, Pasquini L, Narducci R, et al. Anionic conducting composite membranes based on aromatic polymer and layered double hydroxides. International Journal of Hydrogen Energy. 2017;42:3197-205.

[33] Li R, Xu J, Ba J, Li Y, Liang C, Tang T. Facile synthesis of nanometer-sized NiFe layered double hydroxide/nitrogen-doped graphite foam hybrids for enhanced electrocatalytic oxygen evolution reactions. International Journal of Hydrogen Energy. 2018;43:7956-63.

[34] Wu Y, Wang H, Sun Y, Xiao T, Tu W, Yuan X, et al. Photogenerated charge transfer via interfacial internal electric field for significantly improved photocatalysis in direct Z-scheme oxygen-doped carbon nitrogen/CoAl-layered double hydroxide heterojunction. Applied Catalysis B: Environmental. 2018;227:530-40.

[35] Shahrokhian S, Rahimi S, Mohammadi R. Nickel-cobalt layered double hydroxide ultrathin nanosheets coated on reduced graphene oxide nonosheets/nickel foam for high performance asymmetric supercapacitors. International Journal of Hydrogen Energy. 2018;43:2256-67.

[36] Dong X, Zhang Y, Ding B, Hao X, Dou H, Zhang X. Layer-by-layer self-assembled two-dimensional MXene/layered double hydroxide composites as cathode for alkaline hybrid batteries. Journal of Power Sources. 2018;390:208-14.

[37] Ma Y, Wang Y, Xie D, Gu Y, Zhu X, Zhang H, et al. Hierarchical MgFe-layered double hydroxide microsphere/graphene composite for simultaneous electrochemical determination of trace $\mathrm{Pb}(\mathrm{II})$ and Cd(II). Chemical Engineering Journal. 2018;347:953-62.

[38] Mas V, Dieuzeide ML, Jobbágy M, Baronetti G, Amadeo N, Laborde M. Ni(II)-Al(III) layered double hydroxide as catalyst precursor for ethanol steam reforming: Activation treatments and kinetic studies. Catalysis Today. 2008;133-135:319-23.

[39] Romero A, Jobbágy M, Laborde M, Baronetti G, Amadeo N. Ni(II)-Mg(II)-Al(III) catalysts for hydrogen production from ethanol steam reforming: Influence of the activation treatments. Catalysis Today. 2010;149:407-12.

[40] Vizcaíno AJ, Lindo M, Carrero A, Calles JA. Hydrogen production by steam reforming of ethanol using Ni catalysts based on ternary mixed oxides prepared by coprecipitation. International Journal of Hydrogen Energy. 2012;37:1985-92.

[41] Romero A, Jobbágy M, Laborde M, Baronetti G, Amadeo N. Ni(II)-Mg(II)-Al(III) catalysts for hydrogen production from ethanol steam reforming: Influence of the $\mathrm{Mg}$ content. Applied Catalysis $\mathrm{A}$ : General. 2014;470:398-404.

[42] Llorca J, de la Piscina PR, Dalmon JA, Sales J, Homs N. CO-free hydrogen from steam-reforming of bioethanol over $\mathrm{ZnO}$-supported cobalt catalysts: Effect of the metallic precursor. Applied Catalysis B: Environmental. 2003;43:355-69.

[43] Llorca J, Homs N, Sales J, Fierro J-LG, de la Piscina PR. Effect of sodium addition on the performance of $\mathrm{Co}-\mathrm{ZnO}$-based catalysts for hydrogen production from bioethanol. Journal of Catalysis. 2004;222:47080 .

[44] Homs N, Llorca J, de la Piscina PR. Low-temperature steam-reforming of ethanol over ZnO-supported $\mathrm{Ni}$ and $\mathrm{Cu}$ catalysts: The effect of nickel and copper addition to $\mathrm{ZnO}$-supported cobalt-based catalysts. Catalysis Today. 2006;116:361-6.

[45] Yang Y, Ma J, Wu F. Production of hydrogen by steam reforming of ethanol over a Ni/ZnO catalyst. International Journal of Hydrogen Energy. 2006;31:877-82.

[46] Da Costa-Serra JF, Guil-López R, Chica A. Co/ZnO and Ni/ZnO catalysts for hydrogen production by bioethanol steam reforming. Influence of $\mathrm{ZnO}$ support morphology on the catalytic properties of Co and $\mathrm{Ni}$ active phases. International Journal of Hydrogen Energy. 2010;35:6709-16.

[47] Lee Y-K, Kim K-S, Ahn J-G, Son I-H, Shin WC. Hydrogen production from ethanol over Co/ZnO catalyst in a multi-layered reformer. International Journal of Hydrogen Energy. 2010;35:1147-51. 
[48] Sau GS, Bianco F, Lanchi M, Liberatore R, Mazzocchia CV, Spadoni A, et al. Cu-Zn-Al based catalysts for low temperature bioethanol steam reforming by solar energy. International Journal of Hydrogen Energy. 2010;35:7280-7.

[49] Guil-López R, Navarro RM, Peña MA, Fierro JLG. Hydrogen production by oxidative ethanol reforming on $\mathrm{Co}, \mathrm{Ni}$ and $\mathrm{Cu}$ ex-hydrotalcite catalysts. International Journal of Hydrogen Energy. 2011;36:1512-23.

[50] Lucrédio AF, Bellido JDA, Assaf EM. Effects of adding La and Ce to hydrotalcite-type Ni/Mg/Al catalyst precursors on ethanol steam reforming reactions. Applied Catalysis A: General. 2010;388:77-85.

[51] $\mathrm{Hu} \mathrm{X,} \mathrm{Lu} \mathrm{G.} \mathrm{Acetic} \mathrm{acid} \mathrm{steam} \mathrm{reforming} \mathrm{to} \mathrm{hydrogen} \mathrm{over} \mathrm{Co}-\mathrm{Ce} / \mathrm{Al} 2 \mathrm{O} 3$ and $\mathrm{Co}-\mathrm{La} / \mathrm{Al} 2 \mathrm{O} 3$ catalysts - The promotion effect of Ce and La addition. Catalysis Communications. 2010;12:50-3.

[52] Calles JA, Carrero A, Vizcaíno AJ. Ce and La modification of mesoporous $\mathrm{Cu}-\mathrm{Ni} / \mathrm{SBA}-15$ catalysts for hydrogen production through ethanol steam reforming. Microporous and Mesoporous Materials. 2009;119:200-7.

[53] Sánchez-Sánchez MC, Navarro RM, Fierro JLG. Ethanol steam reforming over Ni/La-Al2O3 catalysts: Influence of lanthanum loading. Catalysis Today. 2007;129:336-45.

[54] de Freitas Silva T, Dias JAC, Maciel CG, Assaf JM. Ni/Al2O3 catalysts: effects of the promoters Ce, $\mathrm{La}$ and $\mathrm{Zr}$ on the methane steam and oxidative reforming reactions. Catalysis Science \& Technology. 2013;3:635-43.

[55] Melchor-Hernández C, Gómez-Cortés A, Díaz G. Hydrogen production by steam reforming of ethanol over nickel supported on La-modified alumina catalysts prepared by sol-gel. Fuel. 2013;107:828-35.

[56] Xie R, Fan G, Yang L, Li F. Solvent-free oxidation of ethylbenzene over hierarchical flower-like coreshell structured Co-based mixed metal oxides with significantly enhanced catalytic performance. Catalysis Science \& Technology. 2015;5:540-8.

[57] Busca G, Costantino U, Montanari T, Ramis G, Resini C, Sisani M. Nickel versus cobalt catalysts for hydrogen production by ethanol steam reforming: $\mathrm{Ni}-\mathrm{Co}-\mathrm{Zn}-\mathrm{Al}$ catalysts from hydrotalcite-like precursors. International Journal of Hydrogen Energy. 2010;35:5356-66.

[58] Velu S, Suzuki K. Synthesis and characterization of a new Sn-incorporated CoAl-layered double hydroxide $(\mathrm{LDH})$ and catalytic performance of Co-spinel microcrystallites in the partial oxidation of methanol. In: Sayari A, Jaroniec M, editors. Studies in Surface Science and Catalysis: Elsevier; 2000. p. 451-8.

[59] Wang S-F, Sun G-Z, Fang L-M, Lei L, Xiang X, Zu X-T. A comparative study of ZnA12O4 nanoparticles synthesized from different aluminum salts for use as fluorescence materials. Scientific Reports. 2015;5:12849.

[60] Venugopal A, Palgunadi J, Deog JK, Joo O-S, Shin C-H. Dimethyl ether synthesis on the admixed catalysts of $\mathrm{Cu}-\mathrm{Zn}-\mathrm{Al}-\mathrm{M}(\mathrm{M}=\mathrm{Ga}, \mathrm{La}, \mathrm{Y}, \mathrm{Zr})$ and $\gamma$-Al2O3: The role of modifier. Journal of Molecular Catalysis A: Chemical. 2009;302:20-7.

[61] Cullity BD. Elements of X-ray Diffraction. In: Company AWP, editor.1956. p. 261-2.

[62] Fatsikostas AN, Kondarides DI, Verykios XE. Production of hydrogen for fuel cells by reformation of biomass-derived ethanol. Catalysis Today. 2002;75:145-55.

[63] Fatsikostas AN, Verykios XE. Reaction network of steam reforming of ethanol over Ni-based catalysts. Journal of Catalysis. 2004;225:439-52. 